\title{
PUBLIC POLICIES TO SUPPORT ENTREPRENEURSHIP: DO THEY CONTRIBUTE TO STRENGTHEN SMES SECTOR?
}

\author{
Dragos Dianu1, Monica (Cenan) Ciucos' ${ }^{1}$, Alina Badulescu², Daniel Badulescu ${ }^{2}$ \\ ${ }^{1}$ Doctoral School of Economics, Faculty of Economic Sciences, University of Oradea, \\ Oradea, Romania \\ ${ }^{2}$ Department of Economics and Business, Faculty of Economic Sciences, University of \\ Oradea, Oradea, Romania \\ dianudragos@yahoo.com \\ monica.ciucos@yahoo.com \\ abadulescu@uoradea.ro \\ dbadulescu@uoradea.ro
}

\begin{abstract}
The role of entrepreneurship and private initiative in economic development and jobs creation, for the development of a dynamic and innovative small and medium enterprises (SME) sector is widely recognized in economic theory and practice. Entrepreneurship do not only contribute to productivity improvements, but it could also help finding practical solutions to social and environmental challenges, climate change, global economic or health crises. However, despite this widespread recognition, entrepreneurship relatively recently becomes a concern for the decision-makers', and in many cases the support measures are partial, difficult to understand and access, marked by bureaucracy and over-regulation, even in developed countries. Therefore, the active involvement of policy makers, the contribution of public or private support structures, education, public awareness of the benefits of entrepreneurship and small and medium-sized businesses are essential. Building policies and strategies to support entrepreneurship starts from objective characteristics, but it must be adapted to the specific conditions of each country, the profile, size and structure of the business sector in that country (or region) in order to enhance its contribution to development goals. In our article we state that public policies for entrepreneurship must find a balance between stimulating the new firms' creation, the size of existing ones and the impetus given to the sub-sector of dynamic, innovative companies, high growth-oriented. In the case of the developed countries analysed here, characterized by opportunity-driven entrepreneurship, the objectives of public policies to support entrepreneurship and SMEs should not excessively focus on setting up new companies. Rather, they must insist on creating a business-friendly environment and promoting an entrepreneurial culture, on the efficient functioning of support structures and networks, on encouraging the establishment and development of companies based on high knowledge, on strengthening and growth of the existing SMEs.
\end{abstract}

Keywords: entrepreneurship; SMEs; public policy support, EU.

JEL Classification: L26; H32; M13.

\section{Introduction}

The issue of the role and conduct of public policies in supporting the business sector, and especially small and medium-sized businesses, has a long history in the literature and practice of capitalist countries. Concerns about political support granted, immediately after Second World War, for rebuilding industry, and the challenges of American corporations defined by dynamism, organization, innovation and aggressive expansion all over the world, have raised questions about the optimal size of firms, industrial structure, but also the identification of trends and initiatives necessary to be supported (Audretsch \& Thurik, 2001). The fundamental policy issue confronted by the developed countries in Europe and North 
America at the time was the trade-off between concentration and efficiency on the one hand, and decentralization and democracy on the other. For a long time, policies focused on strengthening public property and severer regulations in terms of competition or antitrust. Although the instruments varied from country to country, they were, in fact, manifestations of a singular political approach - how to restrict, but also to benefit from, the power of the large corporations (Audretsch \& Thurik, 2001), (Audretsch, 2003).

Gradually, the SMEs enter into the attention of public policies, and some of these policies came with measures to support and protect enterprises considered to be, in the capitalist logic, inefficient enterprises, which, if left unprotected, could disappear. The establishment of the Small Business Administration (SBA) in the United States in 1953, as an independent agency of the federal government with a clear mandate to "to aid, counsel, assist and protect the interests of small business concerns, to preserve free competitive enterprise and to maintain and strengthen the overall economy of our nation" (U.S. Small Business Administration (SBA), 2021) is obviously, at least in the trend of that period, an attempt of the US administration to stop the continuous disappearance of small and medium-sized enterprises and to preserve their role in the US economy (Audretsch, 2003).

\section{The reasons and role of public policies to support small and medium-sized businesses}

The rationale and impetus for state involvement in supporting small and medium-sized businesses are based on several deductions and arguments, mostly empirical, and here we refer to the size and pressure of the state apparatus, the specific legislative and regulatory framework and the problem of corruption (Audretsch, 2003).

Regarding the reason of the size and pressure of the state apparatus, it is stated that a strong state sector is associated with an extended state ownership in the economy, and a high pressure of public spending. By default, this leads to a high taxation to cover both the expenses of the state apparatus, but also the high expenses with social insurances (unemployment aids, retirement pension, child allowances etc.). Not infrequently, the increase of such expenses can lead to a decrease in those funds initially allocated to stimulate the establishment of new companies, to tax reductions for small companies or general business incentives. This can be burdensome for certain categories of employees and for entrepreneurs, who are beginning to realize that they are paying more and more money as their business grows. This will reduce the expected profitability of the entrepreneurial activity and the interest for the expansion of the business and will determine a reorientation of the entrepreneurs to the status of employees, or even to inactivity. In other words, the mixture of these individual factors and decisions, combined with the positive or negative effect of various incentives, may lead to the conclusion that an extended state sector will reduce entrepreneurial activity. We must not forget that a powerful state will generate a diverse range of rules and regulations, institutions and bodies for business purposes, generating counter-incentives to enter entrepreneurship. Thus, the action of the institutional framework (initially, apparently well-meant) on the dynamics of firms, will therefore generate a net negative effect, discouraging the firms' creation and endangering the survival of the existing firms (Henrekson, 2007).

In the case of the legislative framework and specific regulations, literature has shown that the effect of regulations (formal or informal) on entrepreneurial activity is also determined by the institutional context, and disparities in entrepreneurial activity between countries or regions can be explained by the quality of support institutions (Baumol, 1990), (Baumol, 1993). Higher levels of regulation will stimulate bureaucracy, will formalize the protection of intellectual property rights and, implicitly, will reduce their efficiency, ending with a negative impact on entrepreneurship. Reciprocally, a business-oriented governmental environment that moderates bureaucracy and over-regulation, with flexible institutions supporting 
entrepreneurial activities, with a governance based on transparency and trust, will positively influence the desire to set up new companies and strengthen the impact of entrepreneurship on the economy and society (North, 1994), (Baumol, 1993), (Davidsson, 1995).

Stronger regulation of the labour market, the level of the minimum wage and rules in wage negotiation, is useful and socially justified, but beyond certain limits, it also has a constraining effect on entrepreneurship and the establishment of new companies, as it restricts the freedom to contract and therefore limits possible combinations of factors of production. Henrekson (2007) states that there are reasons and evidence that such regulations (on employment, firing, minimum wage) are more harmful to smaller and more entrepreneurial employers, compared to larger firms, organized and accustomed in these procedures. Cross-border and regional comparative studies of labour market regulations on SMEs show that in some countries (e.g. the US) low regulations stimulate valuable entrepreneurial firms to grow rapidly and hire staff (keeping self-employment at relatively low levels), while in countries with a complicated regulatory environment, with high labour taxes and regulations, business development is more difficult and risky, so this firms prefer to remain smaller (Szerb, et al., 2013), (Gudici \& Paleari, 2000), (Badulescu \& Badulescu, 2014).

Finally, regarding the problem of corruption, the literature considers them as a negative factor for setting up new companies (by increasing costs and reducing initial expectations for the future of business) and, in the case of already operational companies, by reducing entrepreneurial returns. Researchers and practitioners argue that a corrupt environment generates negative side effects on entrepreneurial supply and transforms entrepreneurs (especially those with strong, market-dominant businesses) in rent-seekers, less interested in innovation, or creating new businesses. Similar to over-regulation, the negative effect of corruption seems to be greater on young, small firms than on already functioning firms, as existing entrepreneurs have acquired certain skills and routines to withstand this corrupt environment, perceived as uncertain and risky by potential entrepreneurs (Estrin, et al., 2013), (European Commission, 2017), (European Commission, 2020a), (Badulescu, 2013a), (Badulescu \& Badulescu, 2014).

Some scholars differentiate between SMEs' policy, considered as "traditional", and entrepreneurial policy, which is relatively new in the public policy landscape (Audretsch, 2003). Thus, the SMEs support policy usually includes measures implemented by a public authority (central or regional) to support and promote existing SMEs, to increase their viability and economic and social impact. On the other hand, entrepreneurial policy has a broader horizon and ambitions, including those measures aimed at stimulating entrepreneurial behavior and directly influencing the level of entrepreneurial vitality in a country or region (Lundstrom \& Stevenson, 2005). Thus, entrepreneurship policy includes both existing and potential entrepreneurs, and the existing stock of SMEs, focusing more on the process of change, while SMEs' policy focuses exclusively on increasing performance and strengthening the existing enterprise. Entrepreneurial policy also takes into account the framework, environmental or individual conditions associated with the decision-making process of entrepreneurs. Entrepreneurial policies have a distinct systemic feature (compared to those for SMEs), they take into account the type and relationships between organizations (firms, clusters, networks, industrial sectors) or spatial dimensions (communities, cities, regions or even a countries), as well as the interactions between these levels.

Usually, the intervention of public policies for entrepreneurship is not necessary justified the association between entrepreneurship and performance, but rather tries to mitigate three fundamental sources of market failure - network externalities, knowledge externalities and learning externalities (Audretsch, 2003).

The externalities of the network result from the fact that local proximity is essential for accessing this dissemination (spill-overs) of knowledge, and the value of an entrepreneurial firm is better highlighted by the (local) presence of other entrepreneurial firms and the formal 
or informal interactions with them (Porter, 2008), (Badulescu, \& Badulescu, 2012). Thus, it is very possible that certain areas, cities or regions, have a remarkable density of entrepreneurship and support structures, small and medium-sized businesses that support and influence each other, and other areas to be avoided, precisely because there is no such a critical mass of companies and entrepreneurs able to drive accelerated business development.

The externalities of knowledge are, according to Arrow (1985) often associated with knowledge, a valuable public good but with a higher degree of uncertainty. Knowledge can drive the rapid development of a company or sector, but at the same time generates a high failure rate of new companies and, implicitly, of those knowledge-based. The externalities of knowledge also include the failure of the market in the evaluation of new (potential) enterprises by private investors, banks and policy makers. Finally, the third source of market failure, the learning externalities, involves the learning effect and this is particularly valuable in regions where entrepreneurship has been relatively absent and there are no strong entrepreneurial traditions. The entrepreneurial spirit generated by existing successful enterprises and entrepreneurial employees (Bosma, et al., 2013), (World Economic Forum \& GEM, 2016), (Badulescu \& Badulescu, 2013b) influences other people. Some of them will find that entrepreneurship is a viable alternative to the current situation and they will be interested in setting up companies and developing entrepreneurial strategies.

Thus, the market failures, inherent in entrepreneurship, require that national, regional or local decision makers to support and promote entrepreneurial initiatives, become partners for the business sector, allowing and encouraging the establishment and development of entrepreneurial firms, creating a virtuous entrepreneurial circle, where entrepreneurs and their firms become powerful and paradigmatic models for others to emulate (Audretsch, 2003).

\section{Public policies to support entrepreneurship and small and medium businesses}

\subsection{From control, regulation and preserving competition, to de-regulation, privatization and support to knowledge-based businesses}

As we already have revealed in the previous paragraphs, since the fifth decade of the last century, public policies aimed to support SMEs moved away from the philosophy of regulation, competition and tempering the dominance of large companies, to encourage successive waves of de-regulation, privatization, and a new approach that stimulates the creation and commercialization of knowledge. Interestingly, although in the case of the first two (de-regulation and privatization), the policy-makers and a large part of influential academic circles had high expectations that they would help the small business sector, from these measures benefited (especially) large corporations. However, the SME sector benefited from the third measure, and especially businesses in the area of research, innovation and development, venture capital and new, growth-oriented enterprises in hightech sectors.

This policy change, to encourage the establishment of new companies and to support the consolidation of existing SMEs, especially those in knowledge-based domains, to stimulate entrepreneurial behaviour through publicly funded programs, is highlighted by the adoption by the US Congress of the Small Business Innovation Research Program (SBIR) in the early 1980s, as a response to the loss of American firms' competitiveness on global markets. Without going into details about the principles of how the program works, there is convincing evidence that the SBIR program has had a positive impact on US economic performance (Lerner, 1999), (Wessner, 2000), (Audretsch, 2003) such as:

- The survival and growth rates of SBIR beneficiaries exceeded those of companies that did not receive SBIR funding; 
- SBIR determined an important number of researchers from top fields (eg bio-medical sciences, ITC) to enter entrepreneurship, to try to commercialize scientific knowledge, boosting the sector of high-tech companies, based on discoveries in science and advanced technology, etc. .;

- Encourage the launch and financing of start-ups in new fields, which otherwise would not have had access to alternative sources of funding;

- A strong demonstrative effect, of emulation and encouragement of the implementation of scientific research results in practice among the scientific communities, universities and research activities.

Various measures and programs such as removing particular bottlenecks in the development and financing of new companies in high scientific research areas, creating innovation centres to support the development of technology-based small companies, research parks to promote and boost the competitiveness of a particular region, incubators and business accelerators, the provision of venture capital for research activities, entrepreneurial education of the younger generations are some of these measures (see Table 1). Shifting the profile of government business support agencies to the regional or local level, transforming them into smaller and more flexible entities, de-regulating and privatizing policies and reinterpreting competition rules, the success of many high-tech clusters that often cross countries border, are the direct result of pro-small business policies.

Table 1: Public programs to assist SMEs and improve entrepreneurial performance

\begin{tabular}{|c|c|c|c|}
\hline $\begin{array}{l}\text { The identified } \\
\text { problem or } \\
\text { weakness }\end{array}$ & $\begin{array}{l}\text { Programs } \\
\text { measures }\end{array}$ & Short description & $\begin{array}{l}\text { Results } \\
\text { comments }\end{array}$ \\
\hline Access to credit & $\begin{array}{l}\text { Various financing } \\
\text { schemes and loan } \\
\text { guarantees }\end{array}$ & $\begin{array}{ll}\text { SMEs without } & \text { own } \\
\text { guarantees } & \text { obtain } \\
\text { access to bank loans, } \\
\text { the government acting } \\
\text { as guarantor }\end{array}$ & $\begin{array}{l}\text { Generally considered } \\
\text { useful, but with little } \\
\text { impact on the overall } \\
\text { financing of SMEs in } \\
\text { most countries }\end{array}$ \\
\hline $\begin{array}{l}\text { Access to } \\
\text { equity financing }\end{array}$ & $\begin{array}{l}\text { Different } \\
\text { investment } \\
\text { schemes }\end{array}$ & $\begin{array}{l}\text { Tax cuts for wealthy } \\
\text { people to encourage } \\
\text { them to become } \\
\text { "business angels " }\end{array}$ & Unclear effects \\
\hline Market access & $\begin{array}{l}\text { Public private, } \\
\text { regional } \\
\text { partnerships }\end{array}$ & $\begin{array}{lr}\text { Encouraging } & \text { trade } \\
\text { between } & \text { various } \\
\text { countries } & \text { under } \\
\text { agreements, unions (e.g. } \\
\text { EU) }\end{array}$ & $\begin{array}{l}\text { Overall satisfaction } \\
\text { among participating } \\
\text { companies }\end{array}$ \\
\hline $\begin{array}{l}\text { The burden of } \\
\text { administrative } \\
\text { regulation }\end{array}$ & $\begin{array}{l}\text { Policies and } \\
\text { promotion of good } \\
\text { practices }\end{array}$ & $\begin{array}{l}\text { Government actions and } \\
\text { targets to significantly } \\
\text { reduce administrative } \\
\text { burdens, to simplify } \\
\text { legislation, especially for } \\
\text { smaller firms }\end{array}$ & $\begin{array}{l}\text { The bureaucratic } \\
\text { burdens are reduced } \\
\text { too slowly and the } \\
\text { reduction of some is } \\
\text { offset by the } \\
\text { emergence of others }\end{array}$ \\
\hline Science parks & $\begin{array}{l}\text { Developments and } \\
\text { investments in } \\
\text { research, } \\
\text { closeness } \\
\text { universities }\end{array}$ & $\begin{array}{l}\text { It seeks to promote and } \\
\text { encourage groups of } \\
\text { companies based on } \\
\text { new technologies }\end{array}$ & $\begin{array}{l}\text { Contradictory } \\
\text { findings on the } \\
\text { impact of these parks } \\
\text { on the companies' } \\
\text { performance }\end{array}$ \\
\hline $\begin{array}{l}\text { Co-working } \\
\text { spaces, }\end{array}$ & $\begin{array}{l}\text { Premises, facilities } \\
\text { and services to }\end{array}$ & $\begin{array}{l}\text { Provides conditions for } \\
\text { an easier "take-off" of }\end{array}$ & $\begin{array}{l}\text { Overall global } \\
\text { recognition of the }\end{array}$ \\
\hline
\end{tabular}


The Annals of the University of Oradea. Economic Sciences

TOM XXX, $1^{\text {st }}$ Issue, July 2021

\begin{tabular}{|c|c|c|c|}
\hline $\begin{array}{l}\text { incubators, } \\
\text { accelerators }\end{array}$ & $\begin{array}{l}\text { support new small } \\
\text { businesses }\end{array}$ & $\begin{array}{l}\text { innovative, ambitious } \\
\text { start-ups }\end{array}$ & $\begin{array}{l}\text { value and } \\
\text { importance of these } \\
\text { initiatives }\end{array}$ \\
\hline $\begin{array}{l}\text { Stimulating } \\
\text { innovation and } \\
\text { research and } \\
\text { development } \\
\text { (R\&D) in small } \\
\text { firms }\end{array}$ & $\begin{array}{lr}\text { Various } & \text { programs } \\
\text { to } & \text { stimulate } \\
\text { research and } \\
\text { innovation in SMEs }\end{array}$ & $\begin{array}{l}\text { Possibility of accessing } \\
\text { funds, on a competitive } \\
\text { basis, to stimulate } \\
\text { additional research and } \\
\text { development in SMEs }\end{array}$ & $\begin{array}{l}\text { Contradictory } \\
\text { findings- it seems to } \\
\text { improve the } \\
\text { performance of } \\
\text { SMEs, but it is } \\
\text { difficult } \\
\text { demonstrate to } \\
\text { they lead to further } \\
\text { R\&D. }\end{array}$ \\
\hline $\begin{array}{l}\text { Stimulating } \\
\text { training and } \\
\text { developing } \\
\text { entrepreneurial } \\
\text { skills in small } \\
\text { businesses }\end{array}$ & $\begin{array}{l}\text { Various programs } \\
\text { to stimulate } \\
\text { entrepreneurial } \\
\text { training in SMEs }\end{array}$ & $\begin{array}{l}\text { Support provided by } \\
\text { government agencies } \\
\text { and local authorities for } \\
\text { the training of small } \\
\text { business owners and } \\
\text { managers, or people } \\
\text { starting a business }\end{array}$ & $\begin{array}{l}\text { Usually, companies } \\
\text { included in these } \\
\text { programs have } \\
\text { higher survival and } \\
\text { growth rates than } \\
\text { expected. There are } \\
\text { also reserved } \\
\text { opinions on their } \\
\text { effectiveness }\end{array}$ \\
\hline $\begin{array}{l}\text { Entrepreneurial } \\
\text { awareness }\end{array}$ & $\begin{array}{l}\text { Various measures } \\
\text { and programs of } \\
\text { entrepreneurship } \\
\text { education }\end{array}$ & $\begin{array}{l}\text { Aiming to develop an } \\
\text { awareness of enterprise } \\
\text { and entrepreneurship in } \\
\text { society, by incorporating } \\
\text { entrepreneurship and } \\
\text { business into the school' } \\
\text { curricula and other forms } \\
\text { of formal and informal } \\
\text { education. }\end{array}$ & $\begin{array}{l}\text { Significant political } \\
\text { and civic support, but } \\
\text { conventional } \\
\text { evaluations are } \\
\text { particularly difficult, } \\
\text { due to long period for } \\
\text { implementation and } \\
\text { impact assessments }\end{array}$ \\
\hline
\end{tabular}

Source: Adapted by authors upon (Audretsch, 2003), (Storey, 1994), (European Commission, 2007), (European Commission, 2006), (Fayolle \& Gailly, 2013), (Ratten \& Usmanij, 2020), (Badulescu \& Petria, 2011).

\subsection{SME support policies in the European Union: The European Charter for Small Enterprises, Small Business Act and related measures}

The European Commission perceives SMEs and entrepreneurship as the key to ensuring growth, innovation, jobs and social integration in the EU (Interreg Europe, 2016), working closely with Member States on developing SME-friendly policies, monitoring progress in their implementation and sharing best practices.

Growing and strengthening the small and medium-sized enterprises (SMEs) sector is a strong goal on the political and economic agenda of the European Union (EU). SMEs are the backbone of the European economy, accounting for $99.8 \%$ of all companies in the nonfinancial business sector (approximative 25 million SMEs), generating more than EUR 3.7 billion in added value (ie almost $57 \%$ of the total added value achieved by the EU business sector) and employing almost 90 million people (67\% of total employment in the EU business sector) in 2019 (European Commission, 2019a).

\section{The European Charter for Small Enterprises}

The beginning of the joint EU's policy for SMEs is linked to the European Charter for Small Enterprises. The first step taken by the European institutions to develop a common SME 
policy took place with the adoption of the European Charter for Small Enterprises (European Commission, 2000) by EU leaders at Feira European Council on 19-20 June 2000. The Charter calls upon Member States and the Commission to take action to support and encourage small enterprises in ten key areas: Education and training for entrepreneurship; Cheaper and faster start-up; Better legislation and regulation; Availability of skills; Improving online access; Getting more out of the Single Market; Taxation and financial matters; Strengthening the technological capacity of small enterprises; Making use of successful ebusiness models and developing top-class small business support; Developing stronger, more effective representation of small enterprises' interests at Union and national level (European Commission, 2000).

\section{Small Business Act (SBA)}

The Small Business Act (SBA) of 2008 defined a general framework of EU SME policy and established the "think small first" principle (European Commission, 2008). The SBA has launched ten principles with a variety of measures through which the EU intends to strengthen SMEs, from facilitating financing, better access to public procurement procedures, to encouraging start-ups and women's entrepreneurship. In addition to its own actions, the European Commission has also made suggestions on how Member States can implement the principles.

The update of this document in 2011, after the economic crisis, by re-evaluating the real effect of the SBA in promoting SMEs, demonstrated the need for a revised policy approach to help companies become stronger, more flexible and faster to respond to global challenges. contemporary. This was confirmed by the conclusions of the Report on the Public Consultation on the "New SME Policy" of 2015 (European Commission, 2015b) which followed other open consultations launched by the European Commission in 2014. According to this Report, a special attention in 6 priority areas: 1 . Reducing the burden on SMEs and simplifying bureaucracy, by creating a business-friendly environment; 2 . Promoting entrepreneurship; 3. Improving market access and internationalization; 4. Facilitating access to finance; 5 . Supporting competitiveness and innovation for, and within SMEs; 6. Providing support networks and information for SMEs. Although in recent years (after 2015) the constant challenges of the business environment, political and social pressures recall the need to revise the SBA, the European Commission's efforts to invigorate and strengthen the private sector have not materialized in a new document, and the revision seems to be postponed for an unknown time in the future.

\section{The SME Performance Review}

According to The SME Policy of the European Union Report (Interreg Europe, 2016), the SME performance analysis is one of the main tools that the European Commission uses to monitor and evaluate countries' progress in implementing the SBA, providing information on the performance of SMEs in EU Member States and partner countries (Interreg Europe, 2016)

\section{Entrepreneurship Action Plan 2020}

The Entrepreneurship 2020 Action Plan aims to unleash Europe's entrepreneurial potential and proposes three main areas of intervention aimed at improving entrepreneurship education and supporting business creation, by strengthen the framework conditions for entrepreneurs by removing existing structural barriers, supporting entrepreneurs in critical stages of the business life cycle and disseminating an entrepreneurial culture in Europe to stimulate the emergence of a new generation of entrepreneurs (Interreg Europe , 2016). 


\section{European SME Week}

European SME Week is a pan-European campaign coordinated by the European Commission. It aims to promote entrepreneurship in Europe through a variety of events across Europe that support information entrepreneurs and encourage as many people as possible to enter the business (Interreg Europe, 2016). Stakeholder feedback has confirmed that, while progress has been made, European entrepreneurs are still not receiving adequate recognition, there are still a small number of people seriously considering becoming entrepreneurs and there is a continuing need to promote entrepreneurship to encourage more people to start their own businesses. Other views insist that more needs to be done to include more real entrepreneurs and SME managers and owners for participants, as well as to ensure a more balanced participation of SME organizations in all Member States, improving access events, attractiveness and updating of the media, so that it is an informative and useful resource to expand its audience (European Commission, 2019).

\section{Enterprise Europe Network (EEN)}

Generally, SMEs operate mainly at regional and national level and quite a few are engaged in cross-border cooperation within the EU or in international affairs (European Commission, 2010), (European Commission, 2020b). A good example and a measure taken in this regard is the Enterprise Europe Network (European Commission, 2020c), which helps European SMEs to develop their business in new markets and to supply or license new technologies, to make the most of opportunities EU business and more. With 600 partner organizations in over 60 countries, the Enterprise Europe Network is the largest SME support network in the world (Interreg Europe, 2016). Organized as a one-stop shop able to meet the various requests for information and cooperation, EEN is based on the involvement of partner organizations that combine international business expertise with local knowledge to help entrepreneurs bring their innovation to European and international markets. It also provides assistance and information on market access, potential legal obstacles and ways to prevent and overcome them, as well as identifying potential business partners across Europe. According to EEN data, over $85 \%$ of SME users are satisfied with its advice. EEN organizes 70,000 international business meetings each year, but no information is provided on the results of these events in terms of practical support for SMEs (European Commission, 2020c). However, the idea of the effectiveness and wide recognition of EEN should be questioned by the data from the recent Flash Eurobarometer survey on the internationalization of SMEs (European Commission, 2015a) according to which only $8 \%$ of EU SMEs have heard of the Enterprise Europe Network, while 92\% stated that they had never heard of such a thing.

\section{Conclusion}

In the first part of this article, we addressed the theoretical and pragmatic reasons and arguments for supporting entrepreneurship and small and medium business, from the size and pressure of the state apparatus, the legislative framework and the impact of corruption, to the more sophisticated arguments of negative externalities generated by market failure this sector. We then reviewed the main steps and measures taken in developed countries (and especially in the US and the European Union) to support SMEs in several specific areas such as simplification of legislation and administrative procedures, promotion of entrepreneurship, internationalization of SMEs, providing information and support networks, etc.

We have found there are claims and arguments that a new revision of these policies (such as the revision of the SBA at EU level) is advisable and even imperative, but this process seems to be delayed. This generates confusion and disappointment on the part of the social partners and business organizations, which anticipate a decline in the focus of decisionmakers on the SME sector in general, or dynamic, growth-oriented start-ups, in particular. 
Our brief analysis also highlights the need to understand how public policies and actions can best recognize and respond to the specific needs of the various subgroups included in the SME category, identifying inequalities in access to SME promotion programs (related to size, location or sector of activity, or the existence of significant transaction costs in accessing support). The right understanding can substantiate recommendations and proposals for improving certain aspects of SME policies and their overall effectiveness; how SME policies and measures could be better targeted and better designed to fit and meet the specific needs of entrepreneurs and companies of different types and sizes that fall within the definition of SMEs, eliminating barriers to their growth.

\section{References}

1. Arrow, K. (1985) The Informational Structure of the Firm. American Economic Review, Vol. 75, pp. 303-307.

2. Audretsch, D. (2003) Entrepreneurship A survey of the literature. Enterprise Papers No. 14, Brussels: Enterprise Directorate-General European Commission.

3. Audretsch, D. andThurik, R. (2001) Linking Entrepreneurship to Growth, OECD Science, Technology and Industry Working Papers, 2001/2, Paris: OECD Publishing.

4. Bădulescu, D. and Petria, N. (2011) Collateral's Importance in SMEs Financing: What Is The Banks' Response? Some Evidence For Romania. The Annals of the University of Oradea. Economic Sciences, XX(1), pp. 256-260.

5. Badulescu, A. and Badulescu, D. (2012). Entrepreneurship and Local Resources. In D. Leslie (ed) Tourism Enterprises and the Sustainability Agenda across Europe. UK: Ashgate Publishing, pp. 151168.

6. Badulescu, D. (2013a) Dezvoltarea și finanțarea afacerilor antreprenoriale. Particularități în turism/Development and financing of entrepreneurial business. Particularities in tourism. Cluj Napoca, Romania: Presa Universitară Clujeană.

7. Badulescu, A. and Badulescu, D. (2013b). How Entrepreneurial are Doctoral Students? Some Evidence from Romania. Journal of Eastern Europe Research in Business \& Economic, Volumul 2013, pp. Article ID 186798, DOI: 10.5171/2013.186798.

8. Badulescu, D. and Badulescu, A. (2014) Antreprenoriatul. Cum, cine, când?. Cluj Napoca, Romania: Editura Presa Universitară Clujeană.

9. Baumol, W. (1990) Entrepreneurship: Productive, Unproductive, and Destructive. The Journal of Political Economy, Vol. 98, No. 5 (Part 1), pp. 893-921.

10. Baumol, W. (1993) Formal Entrepreneurship Theory in Economics: Existence and Bounds. Journal of Business Venturing, Vol. 8, pp. 197-210.

11. Bosma, N. Wennekers, S.; Guerrero, M.; Amorós, J.E.; Martiarena, A.; Singer, S. (2013) Global Entrepreneurship Monitor Special Report on Entrepreneurial Employee Activity, London: Global Entrepreneurship Research Association (GERA).

12. Davidsson, P. (1995) Culture, structure and regional levels of entrepreneurship. Entrepreneurship \& Regional Development, Vol. 7, No. 1, pp. 41-62.

13. Estrin, S., Mickiewicz, T. and Stephan, U. (2013) Entrepreneurship, social capital, and institutions: Social and commercial entrepreneurship across nations. Entrepreneurship Theory and Practice, Vol. 37, No. 3, p. 479-504.

14. European Commission (2000) European Charter for Small Enterprises. Available at: https://ec.europa.eu/growth/content/european-charter-small-enterprises-0 en, [29 March 2021].

15. European Commission (2006) Communication from the Commission "Fostering entrepreneurial mindsets through education and learning" $\operatorname{COM(2006)} 33$ final. [Online], Available at: https://eurlex.europa.eu/legal-content/EN/TXT/?uri=celex\%3A52006DC0033, [11 02 2020].

16. European Commission (2007) Action Programme for Reducing Administrative Burdens in the European Union. [Online], Available at: https://eurlex.europa.eu/LexUriServ/LexUriServ.do?uri=COM:2007:0023:FIN:en:PDF, [12 March 2020].

17. European Commission (2008) Small Business Act. [Online], Available at: http://eurlex.europa.eu/legal-content/EN/TXT/?uri=CELEX:52008DC0394\&locale=en, [02 Feb 2021].

18. European Commission (2010) Business \& Policy Research, 2010. Internationalisation of European SMEs, final report, Brussels: DG Enterprise and Industry. 
19. European Commission (2015a) Flash Eurobarometer 421: Internationalisation of Small and Medium-sized [Online], Available at: https://data.europa.eu/euodp/ro/data/dataset/S2090 421 ENG, [18 April 2020].

20. European Commission (2015b) Report on the public consultation on the "New SME policy". [Online], Available at: http://ec.europa.eu/DocsRoom/documents/8986/attachments/1/translations/en/renditions/pdf, [23 Feb 2021].

21. European Commission (2017) Flash Eurobarometer 457: Businesses' attitudes towards corruption in the EU, s.I.: Directorate-General for Communication.

22. European Commission (2019) European SME week. [Online], Available at: https://ec.europa.eu/growth/smes/support/sme-week en, [19 Feb 2021].

23. European Commission (2020a) Flash Eurobarometer 482 Businesses' attitudes towards corruption in the EU, s.I.: Directorate-General for Communication.

24. European Commission (2020b) SME internationalisation beyond the EU. [Online], Available at: https://ec.europa.eu/growth/smes/access-to-markets/internationalisation en, [21 Aug 2020].

25. European Commission (2020c) Enterprise Europe Network. Available at: https://een.ec.europa.eu/, [02 April 2021].

26. Fayolle, A. and Gailly, B. (2013) The Impact of Entrepreneurship Education on Entrepreneurial Attitudes and Intention: Hysteresis and Persistence. Journal of Small Business Management, doi:10.1111/jsbm.12065.

27. Gudici, G. and Paleari, S. (2000) The Provision of Finance to Innovation: A Survey Conducted among Italian Technology-based Small Firms. Small Business Economics, Vol. 14, No. 1, pp. 37-53.

28. Henrekson, M. (2007) Entrepreneurship and Institutions, IFN Working Paper No. 707.

29. Interreg Europe (2016) Policy Brief. The SME policy of the European Union, Interreg Europe, Policy Learning Platform SME Competitiveness.

30. Lerner, J. (1999) The government as venture capitalist: The long-run effects of the SBIR program. Journal of Business, Vol. 72, pp. 285-297.

31. Lundstrom, A. and Stevenson, L. (2005) Entrepreneurship Policy: Theory and Practice. International Studies in Entrepreneurship, Vol. 9, Boston, MA: Springer, https://doi.org/10.1007/0-38724202-3 1.

32. North, D. (1994) Economic Performance Through Time. American Economic Review, Vol. 84, No. 3, pp. 359-368.

33. Porter, M. (2008) The Five Competitive Forces that Shape Strategy. Harvard Business Review, Vol. 86, No. 1, pp. 79-93.

34. Ratten, V. and Usmanij, P. (2020) Entrepreneurship education: Time for a change in research direction? The International Journal of Management Education, https://www-sciencedirect-com.am.enformation.ro/science/article/pii/S1472811719304641.

35. Storey, D. (1994) Understanding the Small Business Sector. Thomson Learning.

36. Szerb, L. Acs, Z.J.; Autio, E.; Ortega-Argilés, R.; Komlósi, E. (2013) REDI: The Regional Entrepreneurship and Development Index - Measuring regional entrepreneurship, Brussels, Belgium: European Commission, Directorate-General for Regional and Urban policy.

37. U.S. Small Business Administration (SBA) (2021) Organization. Mission. [Online], Available at: https://www.sba.gov/about-sba/organization, [22 March 2021].

38. Wessner, C. (2000) The Small Business Innovation Research Program (SBIR), Washington D.C.: National Academy Press.

39.World Economic Forum \& GEM (2016) Europe's Hidden Entrepreneurs. Entrepreneurial Employee Activity and Competitiveness in Europe, Geneva, Switzerland: World Economic Forum. 